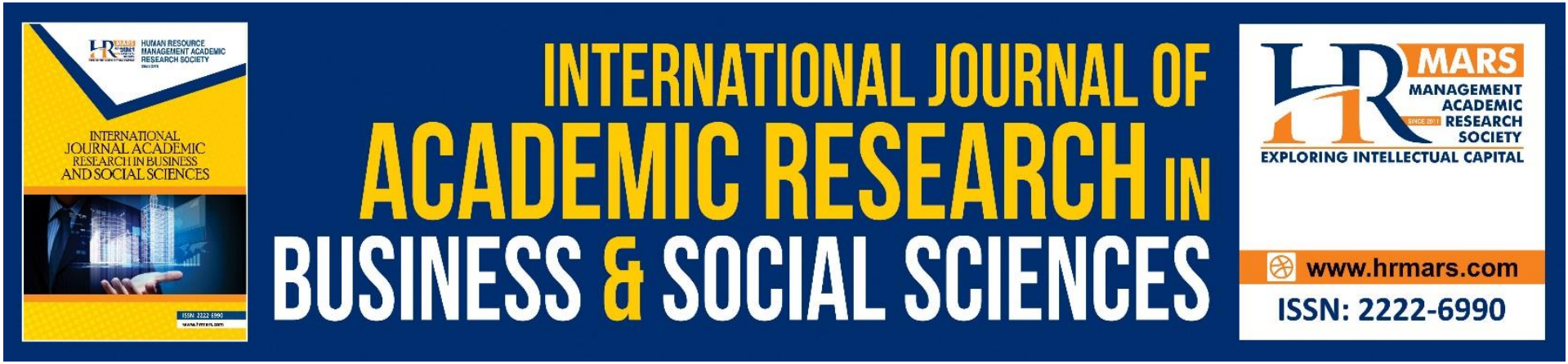

\title{
An Ethical Leader and Corporate Integrity Practices: Lessons Learnt from a Government-Related Company
}

Hanafiah Hasin, Azlina Rahim, Enylina Nordin, Wan Shafizah Hussain, Nor Ashikin Alias

To Link this Article: http://dx.doi.org/10.6007/IJARBSS/v11-i10/11024 ～DOI:10.6007/IJARBSS/v11-i10/11024

Received: 08 August 2021, Revised: 28 August 2021, Accepted: 19 September 2021

Published Online: 10 October 2021

In-Text Citation: (Hasin et al., 2021)

To Cite this Article: Hasin, H., Rahim, A., Nordin, E., Hussain, W. S., \& Alias, N. A. (2021). An Ethical Leader and Corporate Integrity Practices: Lessons Learnt from a Government-Related Company. International Journal of Academic Research in Business and Social Sciences, 11(10), 505 - 518.

Copyright: (c) 2021 The Author(s)

Published by Human Resource Management Academic Research Society (www.hrmars.com)

This article is published under the Creative Commons Attribution (CC BY 4.0) license. Anyone may reproduce, distribute, translate and create derivative works of this article (for both commercial and non-commercial purposes), subject to full attribution to the original publication and authors. The full terms of this license may be seen at: http://creativecommons.org/licences/by/4.0/legalcode

Vol. 11, No. 10, 2021, Pg. $505-518$

http://hrmars.com/index.php/pages/detail/IJARBSS

JOURNAL HOMEPAGE

Full Terms \& Conditions of access and use can be found at http://hrmars.com/index.php/pages/detail/publication-ethics 


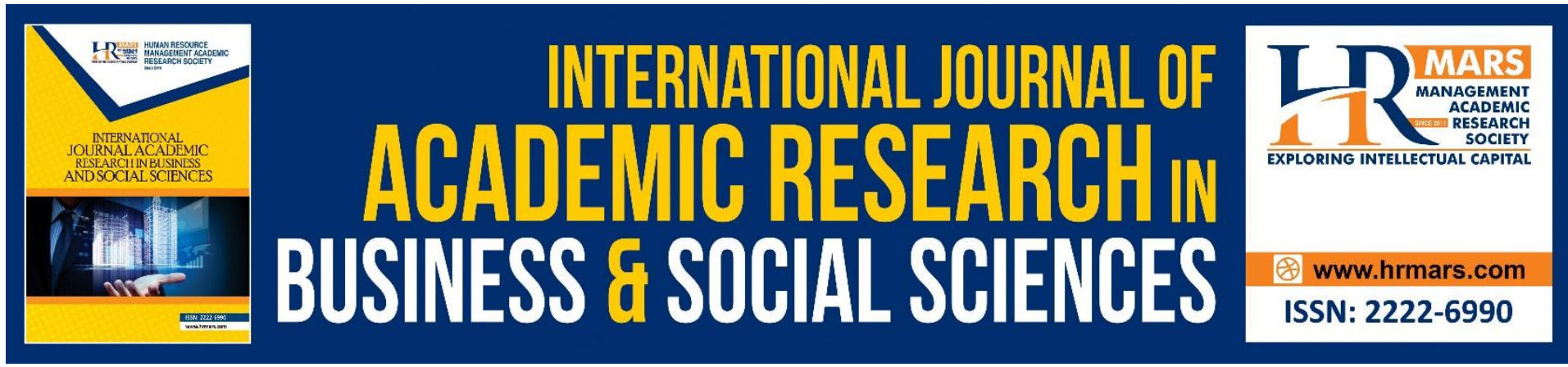

\title{
An Ethical Leader and Corporate Integrity Practices: Lessons Learnt from a Government- Related Company
}

\author{
Hanafiah Hasin ${ }^{1,2}$, Azlina Rahim ${ }^{1}$, Enylina Nordin ${ }^{1}$, Wan \\ Shafizah Hussain ${ }^{1}$, Nor Ashikin Alias ${ }^{1}$ \\ ${ }^{1}$ Faculty of Accountancy, Universiti Teknologi MARA Cawangan Melaka, Kampus Alor Gajah, \\ ${ }^{2}$ Accounting Research Institute, Universiti Teknologi MARA, Selangor \\ Email: hanafiah@uitm.edu.my
}

\begin{abstract}
In Malaysia, an issue of integrity is becoming more attentive. Based on Transparency International's 2020 Corruption Perceptions Index, Malaysia was ranked as the fifty-seventh least corrupt country out of one hundred and eighty countries. Therefore, Malaysia's public and commercial sectors must take responsibility for changing the public's poor impression of the country's integrity system. Since the leader is the most important person in organisational success, this study focuses on discovering how strong the leader applies the integrity system in government-related companies. Data was collected through surveys of executives and managers of GRCs in Malaysia and using a five-point Likert scale. The data gathered was based on respondents' perceptions of the leadership elements of integrity. Our findings indicated that the GRCs had implemented an excellent corporate integrity policy. It confirmed that ethical leadership is an important factor in maintaining the integrity system in the company. Finally, it is anticipated that the research will provide evidence to policymakers to assist them in implementing their strategic strategy to restore Malaysia's positive image in the international community.
\end{abstract}

Keywords: Integrity, Leadership, Ethical, Leader, Government-Related Companies (GRC)

\section{Introduction}

Why does integrity matter in ethical leadership? Integrity in leadership relates to being truthful, dependable, and trustworthy. Leaders who act with integrity are one of the most important factors in creating a pleasant and productive workplace. Leaders with integrity take responsibility for their mistakes rather than denying them, blaming their team, or making excuses for their actions. Honesty and integrity are critical characteristics of a leader in the workplace. To guarantee people have faith in their interests and honesty, the leader should build strong working connections with employees and business members. Leadership developed positive thinking, which increased employee commitment to their work (Park \& Hwang, 2015). Nangoli et al (2020) supported this argument when leadership is reliable and honest, encouraging the employees to accept more responsibilities. 
Leadership is all about having others follow your rules and doing things the right way (Yukl, 2010). In agreement with many other organisational theorists and practitioners, Parry \& Proctor-Thomson (2002) noted that many researchers and business professionals believe that the firm will fail without integrity in leadership.

One of the important things to look at when judging a leader is how leaders show values and convince others to follow. A good character in a leader can help impact the attitudes and values of their employees (Avolio \& Gardner, 2005). When a leader acts, it reflects on them as well as on their organisation's reputation. Integrity makes leaders more trustworthy and, thus, more likely to inspire their teams to do their best work. Leaders that encourage their staff to express their opinions and ideas have a higher chance of influencing them, according to the research of Chen et al (2010). Leaders who receive high ratings for integrity can create trust among their employees. Employees who trust their bosses will thus work more, perform better, and be more dedicated to the company (Chi and Chi, 2014). Bateman et al (2012) also support that most employees demand a high level of integrity from their leaders. Kalshoven et al (2011) concluded that integrity is considered one of the key traits of leaders in ethical leadership.

In essence, integrity means doing what is in the best interests of others. In Webster's definition, corporate integrity is the state or condition of management and shareholders having full intentions. Acting for the company's best interest, the public, and the company stakeholders is social responsibility. Mc Cann (2009) observed that unethical behaviour is on the rise because leaders must meet rigorous standards of integrity. For Krylova et al (2017), integrity is linked to constructed values like morality and honesty, ethics, and sincerity. The same argument was also supported by Thoroughgood et al (2013). In contrast, Bogan \& Dedeoglu (2017) believe it is critical to instil individuals and organisations with a positive attitude toward integrity.

The OECD (2013) defines government integrity as the alignment of government and public institutions with larger values and norms of behaviour that preserve the public interest while avoiding corruption. Corruption is a major global factor affecting citizens' trust in government. Keele (2007) highlighted that public service quality might also affect the people's trust in the government. Because of consumer satisfaction, individuals tend to trust their government more if they are happy (Christensen \& Legreid, 2005). Asia's rampant political corruption compromises the integrity of government (Chang \& Chu, 2006). Another study by Goodsell (2006) asserts that government corruption has had a significant impact on society. According to Christensen \& Legreid (2005), government sector confidence affects other government sectors. Thus, government integrity can also be determined by the effectiveness with which a country's laws and regulations are enforced (La Porta et al., 1998; Rothstein \& Teorell, 2008), implying that it is a public perception based on the efficiency or inefficiency of formal institutions.

Numerous characteristics comprise or contribute to the whole of national culture. For instance, government integrity, defined as the quality of national governance that adheres to appropriate moral principles and standards, such as consistency, coherence, lawfulness, and the lack of corruption (OECD, 2013), is inextricably linked to national culture. To maintain a culture of integrity, increasing leaders' confidence in their workers was crucial, according to Grover et al (2014). As found in earlier studies by Thoroughgood et al (2013), supporting evidence is also found in this study. According to prior research, integrity has been identified as one of the most important characteristics of leaders in ethical leadership (Kalshoven et al., 2011). Good leadership is required for a successful company, and leaders with integrity are 
expected to apply a strong integrity system in the company. In addition, Philip (2013) discovered that leadership associated with government-related companies must develop a comprehensive integrity system for their leaders to have integrity. It follows that to keep public and private sector entities accountable, they must enhance their internal control with a prevention control system that can provide positive leadership, ethical administration, openness, and accountability. Thus, integrity is a crucial aspect to consider, and it has long been recognised as a necessary characteristic for governments to possess to attain sustainable development goals (SDG) (OECD, 2013).

Therefore, based on the above review, this study intends to discover how strong the leader applies the integrity system in government-related companies. A case study approach was employed in this research to investigate how leadership integrity affects the application of integrity in government-related companies. Thus, the findings are anticipated to aid in implementing the country's strategy to rebuild its reputation and restore the nation's dignity.

\section{Literature Review}

Malaysia has been perceived as being corrupt, which limits opportunities. Based on Transparency International's 2020 Corruption Perceptions Index, Malaysia was ranked fiftyseventh least corrupt country out of one hundred and eighty countries. Therefore, Malaysia's public and commercial sectors must take responsibility for changing the public's poor impression of the country's integrity system. To stop unethical practices, the Malaysian government should become involved and collaborate with other businesses. The addition of confidence to international investors' minds is vital to maintain Malaysia's commercial competitiveness. To reduce the likelihood of corruption, Malaysia established the Malaysia Institute of Integrity (INTEGRITI). This government-run initiative aims to enhance the efficacy and efficiency of the public sector while also helping implement the National Integrity Plan. The nation will succeed if it stays true to its ideals and integrity. Integrity is essential, particularly in government. If an individual or entity is not doing what they say they will, it might be because of corruption, incompetence, or fraud. Integrity in the company is essential for long-term viability (Brotherton, 2011; Ejiofor, 1987). Furthermore, integrity must be exhibited across individuals and institutions that support the country's growth to a highincome economy (Aziz, 1999). Corruption was a major issue in the social sciences, particularly in the fields of organisational and ethical behaviour, according to Rodriguez (2005). Good governance, strategic planning, audit and fraud control are all important in the public sector, particularly in Malaysia. For an organisation, ethical behaviour is an example of operating in accordance with established moral ideals, norms, and rules (Kolthoff et al., 2010; Bauman, 2013). Promoting excellent values has a notable influence on honesty and responsibility, according to Mintrop (2012).

\section{Leadership}

Leadership definitions are different depending on who you ask, and they have changed over time. Current leadership ideas have a tremendous gap when compared to classic leadership theories. Due to the large amount of research that has been done, most studies show that leadership styles have evolved considerably over history. The current forms of leadership are much superior to their predecessors. The success or failure of an organisation depends greatly on the leader's performance. Ladkin (2020) stated that leadership requires motivating employees to achieve collective goals by directing them ahead of Maslow's hierarchy needs. He believes that leadership and directing are the same and part of the manager's roles. 
Kristiano et al (2018) said that leaders do not stand aside but rather encourage people and stand in front to facilitate progress. Hersey and Blanchard (1969) defined leadership in the organisation as the process to achieve the organisation's goals with the help of others. Philip (2013) points out that everyone wants to discover the key variables contributing to extraordinary leadership.

Leadership is the capacity of an individual to influence others to assist an organisation in accomplishing its mission (Philip, 2013). This effect is derived from having a management position or from observation or personal effort. Effective leadership improves an organisation by preparing the next generation of competent leaders to take the firm to the next level. No leader holds all the power, but every leader can wield power. A leader needs to be devoted, diligent, and have a lot of personal effort and energy. Good leadership qualities can be developed by learning, observing, and influencing your surroundings. Thus, everyone could be a skilled leader. It is common for everyone to have the opportunity to improve their exceptional leadership abilities by demonstrating and communicating their expertise. Nollenberger (2006) believes that a combination of personal talents and abilities will lead to strong leaders eventually being significant successes for their organisations. Strong leadership skills include seeing the organisation's objective, getting people motivated, becoming a source of inspiration for the organisation, and developing innovative ways to achieve the organisation's goals. Being a good and respected leader, Philip (2013) provided a list of traits. These traits are based on an individual's habits, customs, and dedication. Among the traits are that the leader must engage with the workforce and gain first-hand knowledge of these issues and problems. Doing so will accurately assess the company's facilities, allowing the leader to understand the values necessary for employee reinforcement.

Furthermore, leaders must foster open and positive relationships with everyone in the organisation by developing warm connections with those at all levels of the workforce and reacting to problems in a professional manner. Additionally, a leader must be effective in influencing or persuading people while also helping staff collaborate in pursuing outstanding results. Lastly, a significant factor in determining whether or not someone is a successful leader is their ability to make ethical judgments. A leader must be consistent and empathetic toward their employees to earn their trust and increase their productivity. After that, a leader must be willing and able to meet all other leaders' problems and challenges. It is in accordance with Parry (2002). Hasin et al (2020) considered managing the organisation ethically as one of the leadership competencies.

Furthermore, to become a great leader, a person must deal positively with high levels of pressure. The leader sets an explicit objective for the organisation, ensuring that people have faith and trust. Additionally, strong communication is an important element for effective leadership, and as such, the leader must be skilled in communicating with all their staff. And last, it is necessary to have influence and authority and to have a strong vision as qualities of a successful leader. Increasing the motivation level of an employee in pursuit of the organisation's goals would improve productivity.

\section{Leadership and Integrity}

Adeoye (2009) defines leadership as assessing and project a long-term plan or policy and guiding employees to achieve those goals. The integrity of companies and markets is critical to a country's long-term well-being and prosperity. Corporate governance is defined as the rules and procedures that regulate relationships between the shareholders and management of businesses and the connection between stakeholders and creditors. "Gain, and financial 
stability could promote confidence in the market, the integrity of the financial market, and economic efficiency." Leipziger (2015) asserts that sound corporate governance can result in growth and financial stability, thereby fostering market confidence, financial market integrity, and economic efficiency. The organisation's business value may be produced, and the danger of failure can be significantly reduced since the company can get and completely utilise all of the external sources of finance. In line with a previous study conducted by Pham (2016), strong corporate governance is a key determinant in firm performance.

Personal integrity is associated with leadership. The organisation should have a high personal integrity leader to achieve its purpose and assure its success. Honesty and leadership go sideby-side. Integrity implies acting according to moral and ethical principles in all situations. Employees will contribute to their maximum capacity and inspire goodwill if they are treated with honesty and respect. Leadership integrity can impact employee productivity in dualstrategy and non-strategy firms (Wei et al., 2020). The findings highlight the significance of a leader's behavioural integrity and work resources in facilitating the reception of team members' supporting behaviours, which, in turn, invigorate employee in-role performance (Choi et al., 2020). Similarly, Verissimo and Lacerda (2015) found that leadership integrity increases employee engagement and acceptance of duties, increasing employee productivity (Moorman et al., 2018).

Successful leadership was associated with integrity, which was required for superior organisational performance (Storr, 2004). Additional findings of Yukl et al (2013) revealed not only are honesty, integrity, ethical conduct, decision-making fairness, and an attitude that promotes kindness and compassion important, but they were also all interrelated. However, leaders are typically placed in tough situations, requiring them to deal with severe moral problems. They see a pressing necessity to conform to numerous misdeeds and unconscionable choices with which they would never think to worry themselves. An organisation has lost credibility because its officials exploit their positions of authority for their benefits, such as graft, bribery, deception, misappropriation, embezzlement, and even extortion (Kohlberg, 1969). Leaders that have high integrity keep their focus and work to make ethical judgments. A responsible leader will avoid engaging in or making unethical decisions. Hasin et al (2020) stated that a leader could influence the employee to apply strong integrity in the organisation. It will help leaders managing the organisation ethically. Leadership, whether in the public or private sector, achieves organisational effectiveness by coordinating the implementation of ethical codes of conduct and using tailored interventions and disciplines to prevent corruption (Transparency International, 2019).

\section{Government-related Companies}

In Malaysia, businesses referred to as Government-related Companies (GRCs) hold a principal trade objective. Ownership is directly controlled by the state, regardless of the percentage of shares that the government has. In addition, Malaysian government authorities hold a significant stake in these companies due to their direct influence over directors and senior management personnel appointments. The government can decide on policy matters, such as planning and contracting, and operational aspects, such as acquisition and divestiture choices. About managing the GRCs of Malaysia, Khazanah Nasional (which manages all the stateowned investment funds) was entrusted and given the duty by the government (Malaysia Productivity Corporation; Khazanah Nasional Berhad), whose market share adds $36 \%$ to the market capitalisation. 
An inquiry was started by the anti-corruption agency in 2018 into a government-related company involved in oppressive and corrupt activity, which totalled RM108.57 million. The complaint asserts that the Malaysian Anti-Corruption Commission (MACC) received an allegation that a shipyard employee allegedly worked with contractors to submit fraudulent repair claims. The investigation team has recorded testimonies from another nine witnesses, includes four high-ranking officials of the GRC (Star, 2018). Due to failure to address major scandals, our former Prime Minister, Tun Dr Mahathir Mohamad, created the country's first unit dedicated to integrity and governance at GRCs and state-owned enterprises. The new system began on October 1, 2018. Aiming to make Malaysia a corruption-free country, the government has decided to increase corporate integrity and governance among all GRCs. The Integrity and Governance Unit (IGU) implementation will see the creation of a new department under the company's board of directors. MACC will monitor the execution and reporting.

\section{Methodology}

Quantitative data analysis was used for this research as the most acceptable approach for analysis. The single company under the Ministry of Finance has been designated as an understudy for the government and referred to as a government-related company. It will be important to this study whether the level of corporate integrity system adopted by the GRC is high or not. Questionnaire survey collection is a means of collecting data in the data collection process. Out of 120 questionnaires given to various management levels in the company, 55 were returned. The Malaysian Institute of Integrity designed the corporate questionnaire and used it to collect the necessary data.

The questionnaire has two parts. Section A contains demographic data such as gender, education level, and some services provided. Section B, on the other hand, seeks information on the company's Integrity system. The questionnaire uses a 5-point Likert scale. It has 21 elements. 
Table 1 corporate integrity system - leadership component

\begin{tabular}{|c|c|}
\hline No & lements \\
\hline LIS1 & $\begin{array}{l}\text { Ethics and integrity are neglected or lack leadership, engagement, and } \\
\text { responsibility. }\end{array}$ \\
\hline LIS 2 & rs believe their ethical values will drive the company, \\
\hline LIS 3 & Our I \\
\hline LIS 4 & tegrity as being mostly a responsibility of \\
\hline LIS 5 & $\begin{array}{l}\text { Most managers and supervisors assume some degree of personal } \\
\text { accountability for ethical conduct. }\end{array}$ \\
\hline LIS 6 & I lodorc rouir \\
\hline LIS 7 & An $e$ \\
\hline LIS 8 & 'obligations. \\
\hline LIS 9 & $\begin{array}{l}\text { Ethical conduct is one of our managers' and supervisors' obligations, and } \\
\text { they are held accountable for their behaviour. }\end{array}$ \\
\hline LIS 1 & $\begin{array}{l}\text { At the management level, our leadership considers ethics and integrity to } \\
\text { influence the bottom line directly. }\end{array}$ \\
\hline
\end{tabular}

LIS 11 The link between "tone from the top" and how positively an organisation is seen for ethics is something our leaders recognise.

LIS 12 It is demonstrated that leaders and managers possess ethical consciousness. They are well acquainted with the words of ethical analysis and always do their duties in a manner that is in harmony with the company's stated values.

LIS 13 People commonly use the words ethics and integrity while speaking to a wide range of people.

LIS 14 Board members are held accountable for promoting ethical practices inside the company.

LIS 15 Ethics training and mentoring are provided to our managers by others.

LIS 16 Ethical awareness, analysis, and action are frequently embedded in decisions about who is chosen, who gets high-performance ratings, and who is given bonuses.

LIS 17 Management compensation, incentives, and promotions are connected to ethical standards, including philanthropy and employee well-being.

LIS 18 Ethical management is viewed as a vital leadership capability.

LIS 19 Many people look up to our senior executives as role models.

LIS 20 Leaders show their support for ethics and integrity efforts by openly supporting them.

LIS 21 Our executives have a strong moral basis and believe that ethical behaviour is critical to the organisation's culture.

Table 1 provides information on the leadership component of the corporate integrity system, and 21 elements were requested to be assessed by the respondents. Respondents were asked to rank their responses on a 5-point scale. "0" means "not sure"; "1" means "strongly disagree"; "2" means "disagree"; "3" means "agree"; and "4" means "strongly agree." "At least agree" is specified using Scales of 3 and 4 ; "disagree" is specified using Scales of 1 and 2. If an unaddressed question remained, it was marked as "0". 


\section{Findings}

Demographic information

Table 2 Demographic information

\begin{tabular}{lll}
\hline & Frequency & Percent \\
\hline Gender & & \\
\hline Female & 37 & $67.27 \%$ \\
\hline Level of education & 18 & $32.73 \%$ \\
\hline Diploma & & \\
Bachelor Degree & 17 & $30.91 \%$ \\
Profesional & 31 & $56.36 \%$ \\
Others & 1 & $1.82 \%$ \\
Year of service in GRC & 6 & $10.91 \%$ \\
\hline More than five years & & \\
5 to 10 years & 9 & $16.36 \%$ \\
Ten years and above & 33 & $60.00 \%$ \\
\hline
\end{tabular}

Table 2 shows the company demographic information consisting of gender, level of education and year of services in the GRC. Male respondents represent $62.27 \%$ meanwhile female respondents represent $32.73 \%$. Table 2 indicates that $17(30.91 \%)$ respondents are diploma holders, 31(56.36\%) are degree holders, 1 (1.82\%) and $6(10.91 \%)$ are professional qualification and others, respectively. The frequency of the year services in GRC represents $16.36 \%$ ( 5 years and above), whereas 5 to 10 years and more than ten years are $60.00 \%$ and $23.64 \%$, respectively. 


\section{A Descriptive Analysis of Leadership Component}

Table 3 Descriptive analysis on leadership component

\begin{tabular}{|c|c|c|c|c|c|}
\hline Rank & Elements & Min & Max & Mean & $\begin{array}{l}\text { Std } \\
\text { Deviation }\end{array}$ \\
\hline LIS10 & $\begin{array}{l}\text { At the management level, our leadership } \\
\text { considers ethics and integrity to influence } \\
\text { the bottom line directly. }\end{array}$ & 1 & 4 & 3.40 & .705 \\
\hline LIS18 & $\begin{array}{l}\text { Ethical management is viewed as a vital } \\
\text { leadership capability. }\end{array}$ & 0 & 4 & 3.40 & .859 \\
\hline LIS12 & $\begin{array}{l}\text { It is demonstrated that leaders and } \\
\text { managers possess ethical consciousness. } \\
\text { They are well acquainted with the words } \\
\text { of ethical analysis and always do their } \\
\text { duties in a manner that is in harmony with } \\
\text { the company's stated values. }\end{array}$ & 1 & 4 & 3.38 & .733 \\
\hline LIS9 & $\begin{array}{l}\text { Ethical conduct is one of our managers' } \\
\text { and supervisors' obligations, and they are } \\
\text { held accountable for their behaviour. }\end{array}$ & 0 & 4 & 3.33 & .734 \\
\hline LIS11 & $\begin{array}{l}\text { The link between "tone from the top" and } \\
\text { how positively an organisation is seen for } \\
\text { ethics is something our leaders recognise. }\end{array}$ & 2 & 4 & 3.29 & .626 \\
\hline LIS14 & $\begin{array}{l}\text { Board members are held accountable for } \\
\text { promoting ethical practices inside the } \\
\text { company. }\end{array}$ & 1 & 4 & 3.29 & .688 \\
\hline LIS15 & $\begin{array}{l}\text { Ethics training and mentoring are } \\
\text { provided to our managers by others. }\end{array}$ & 0 & 4 & 3.25 & .688 \\
\hline LIS17 & $\begin{array}{l}\text { Management compensation, incentives, } \\
\text { and promotions are connected to ethical } \\
\text { standards, including philanthropy and } \\
\text { employee well-being. }\end{array}$ & 1 & 4 & 3.14 & .833 \\
\hline LIS16 & $\begin{array}{l}\text { Ethical awareness, analysis, and action are } \\
\text { frequently embedded in decisions about } \\
\text { who is chosen, who gets high- } \\
\text { performance ratings, and who is given } \\
\text { bonuses. }\end{array}$ & 0 & 4 & 3.12 & .934 \\
\hline
\end{tabular}

Respondents of the study were presented with 21 elements on the corporate integrity system's leadership component. On the integrity system, at least nine of the 21 elements have a mean of greater than three, demonstrating that they are at least on the same page with the dimensional value assigned. The findings of the descriptive analysis, including the leadership element rankings, are shown in Table 3. The highest score is 3.40 (At the management level, our leadership considers ethics and integrity to influence the bottom line directly). This finding confirmed that ethical leadership is an important factor in maintaining the integrity system in the company. It confirmed that leaders applied high integrity system in GRC. The results of this study agreed with (Kalshoven et al., 2011; Philip, 2013; Rosli et al., 2015; Bogan \& Dedeoglu, 2017). 


\section{Discussion, Conclusions and Limitations}

The objective of this study is to analyse corporate integrity practises in Malaysia. This study focuses on how integrity in leaders affects the company's level of integrity. After considering the results of questionnaires sent to managers and executives of a GRC in Malaysia, it has been concluded that the case company has applied strong corporate integrity practices in place lead by the ethical leader. The results of a case study of a GRC in Malaysia revealed that the organisation had excellent corporate integrity policies in place with support from the ethical leader. The results agreed with other studies Kalshoven et al (2011); Philip (2013); Rosli et al (2015); Bogan \& Dedeoglu (2017) and revealed that it is critically important to uphold ethical standards in leadership.

Furthermore, based on the findings, successful corporate integrity is implemented when all these variables are fully utilised. As a leader, they need to motivate their employees to handle their job with integrity. Based on Maslow's (1954) hierarchy of needs and theories of motivation, the needs at the bottom of the pyramid, physiological needs (food, water, and shelter) need to be satisfied before a higher level of needs (self-actualisation) can be satisfied. To help employees satisfy esteem and self-actualisation needs, leaders should endeavour to fulfil the most pressing needs at each level. Leaders can use the hierarchy of needs in strategic and operational to create a positive work environment and increase employee motivation. Therefore, a leader who can satisfy their employees need can expect to receive support from their employees. Therefore, a high integrity system can be implemented in the company, bringing a good image to the company.

In conclusion, an ethical leader in the public sector in Malaysia manages to motivate their employees to have high integrity while performing their work. This result shows that government-related companies can help rebuild the image and right the wrong impression towards the government of Malaysia. The findings will be useful for policymakers to adopt policies and processes to establish more transparent and efficient government-related companies in Malaysia. It is useful for the public to know the positive result towards integrity in the government-related companies obtained from this study. When leaders are ethical, they will always perform their work with high integrity, and the employees will be motivated to follow their leader. Thus, it will establish a strong integrity system in government-related companies. Based on that, this study contributes to the existing literature on integrity and leadership. This study helps to right the negative perception of Malaysia as a corrupt country, and it is recommended that more research be done to help the government clear the bad image of the country then the trust of the public can be developed. However, the finding only supports government-related companies. Therefore, more studies can be done and extended to other government agencies or sectors; this will contribute more to the literature in this field.

\section{References}

Adeoye M. (2009). Leadership by Scholars. http://adeoyemayowaleadership.blogspot.co.uk/ Avolio, B. J., \& Gardner, W. L. (2005). Authentic leadership development: Getting to the root of positive forms of leadership. The leadership quarterly, 16(3), 315-338.

Aziz, T. A. (1999). Malaysia incorporated: Ethics on trial. Australian Journal of Public Administration, 58(4), 19-25.

Bateman, H., Eckert, C., Geweke, J., Louviere, J., Thorp, S., \& Satchell, S. (2012). Financial competence and expectations formation: Evidence from Australia. Economic Record, 88(280), 39-63. 
Bauman, D. C. (2013). Leadership and the three faces of integrity. The leadership quarterly, 24(3), 414-426. https://doi.org/10.1016/j.leaqua.2013.01.005

Boğan, E., \& Dedeoğlu, B. B. (2017). The effects of perceived behavioral integrity of supervisors on employee outcomes: Moderating effects of tenure. Journal of Hospitality Marketing \& Management, 26(5), 511-531.

Brotherton, P. (2011). Corporate Integrity Pays Off in Better Performance. T+ D, 65(1), 24-24.

Chang, E. C., \& Chu, Y. H. (2006). Corruption and trust: exceptionalism in Asian democracies?. The Journal of Politics, 68(2), 259-271.

Chen, C. C., \& Farh, J. L. (2010). Developments in understanding Chinese leadership: Paternalism and its elaborations, moderations, and alternatives. In M. Bond (Ed.), Oxford handbook of Chinese psychology (pp. 599e622). Oxford: Oxford University Press.

Chi, J. L., \& Chi, G. C. (2014), "Perceived executive leader's integrity in terms of servant and ethical leadership on job burnout among christian healthcare service providers", Journal of Management and Research, Vol. 14, pp. 203-226.

Choi, Y., Yoon, D., \& Kim, D. (2020). Leader Behavioral Integrity and Employee In-Role Performance: The Roles of Coworker Support and Job Autonomy. International Journal of Environmental Research and Public Health, 17(12), 4303. MDPI AG. Retrieved from http://dx.doi.org/10.3390/ijerph17124303

Christensen, T., \& Lægreid, P. (2005). Trust in government: The relative importance of service satisfaction, political factors, and demography. Public performance \& management review, 28(4), 487-511.

Corruption perceptions index. (2020). Retrieved from https://www.transparency.org/en/cpi/2020/index/nzl\#

Corruption perceptions index 2018. (2019). Retrieved from https://www.transparency.org/whatwedo/publication/corruption_perceptions_index_ 2018

Ejiofor, P. N. (1987). Management in Nigeria: Theories and issues. Africana-FEP Publishers.

Goodsell, C. T. (2006). A New Vision For Public Administration. Public Administration Review. ProQuest Education Journals, 66(4), 623-635.

Grover, S. L., Hasel, M. C., Manville, C., \& Serrano-Archimi, C. (2014). Follower reactions to leader trust violations: A grounded theory of violation types, likelihood of recovery, and recovery process. European Management Journal, 32(5), 689-702. http://doi.org/10.1016/j.emj.2014.01.002.

Hasin, H., Rahim, A., Nordin, E., Hussain, W. S., Alias, N. A., \& Said, J. (2020). INFLUENCE OF LEADERSHIP IN IMPLEMENTING AN INTEGRITY SYSTEM IN A GOVERNMENT LINKED COMPANY IN MALAYSIA. Asia-Pacific Management Accounting Journal, 15(2), 47-63.

Hersey, P. \& Blanchard, H. K. (1969). Management of organisational behavior: Utilising human resources. Englewood Cliffs, N.J.: PrenticeHall.

Kalshoven, K., Den Hartog, D. N., \& De Hoogh, A. H. (2011). Ethical leadership at work questionnaire (ELW): Development and validation of a multidimensional measure. The leadership quarterly, 22(1), 51-69.

Keele, L. (2007). Social capital and the dynamics of trust in government. American Journal of Political Science, 51(2), 241-254.

Kolthoff, E. (2010). The importance of integrity in the security profession: Bringing in human rights. Ethics and Security, The Hague, Eleven Publishing, 39-55.

Kohlberg, L. (1969). Stage and sequence: The cognitive-developmental approach to socialisation. Handbook of socialisation theory and research, 347, 480. 
Kristiano, P. B., Rivai, A., \& Suharto, E. S. (2018). The influence of leadership style and organisational climate on employee performance through organisational commitment on Perum Pegadaian Branch East Bekasi. International Journal of Business and Applied Social Science (IJBASS), 4(6), 34-51

Krylova, K. O., Jolly, P. M., \& Phillips, J. S. (2017). Followers' moral judgments and leaders' integrity-based transgressions: A synthesis of literatures. The Leadership Quarterly, 28(1), 195-209.

Ladkin, D. (2020). Rethinking leadership: A new look at old questions. Edward Elgar Publishing. Leipziger, D. (2015). Economic transformation lessons from large developing countries. London: SET Programme, ODI. https://set. odi. org/economic-transformationlessons-from-large-developing-countries.

Maslow, A. (1954), Motivation and Personality, Harpers, New York.

McCann, J., \& Holt, R. (2009). Ethical leadership and organisations: An analysis of leadership in the manufacturing industry based on the perceived leadership integrity scale. Journal of business ethics, 87(2), 211-220.

Mintrop, H. (2012). Bridging accountability obligations, professional values and (perceived) student needs with integrity. Journal of Educational Administration.

Moorman, R. H., Blakely, G. L., \& Darnold, T. C. (2018). Understanding how perceived leader integrity affects follower trust: Lessons from the use of multidimensional measures of integrity and trust. Journal of Leadership \& Organizational Studies, 25(3), 277-289.

Nangoli, S., Muhumuza, B., Tweyongyere, M., Nkurunziza, G., Namono, R., Ngoma, M., \& Nalweyiso, G. (2020), "Perceived leadership integrity and organisational commitment", Journal of Management Development, Vol. 39 No. 6, pp. 823834. https://doi-org.ezaccess.library.uitm.edu.my/10.1108/JMD-02-2019-0047

Nollenberger, K. (2006). Combining leadership and management skills. Government Finance Review, 22(4), 28.

OECD. (2013). Recommendation of the Council on Public Integrity. Paris: OECD.

Park, M. H., \& Hwang, C. J. (2015). Relationship between servant leadership of nurse managers and positive thinking and organisational commitment of nurses. Korean Comparative Government Review, 19(1), 49-77.

Parry, K. W., \& Proctor-Thomson, S. B. (2002). Perceived integrity of transformational leaders in organisational settings. Journal of business ethics, 35(2), 75-96.

Pham, H. (2016). An Empirical Research on the Relationship between Leadership Behavior and Employee Engagement within Virtual-working Environment at Technology Enterprises in Vietnam. Available at SSRN 2838542. https://doi.org/10.2139/ssrn.2838542

Philip, T. A. (2013). Perception of leadership style, leadership effectiveness, and leadership integrity: A correlation of follower's assessment. A Dissertation. Minnesota: Capella University.

Porta, R. L., Lopez-de-Silanes, F., Shleifer, A., \& Vishny, R. W. (1998). Law and finance. Journal of political economy, 106(6), 1113-1155.

Rodriguez, P., Uhlenbruck, K., \& Eden, L. (2005). Government corruption and the entry strategies of multinationals. Academy of management review, 30(2), 383-396.

Rosli, M. H., bin Abd Aziz, M. A., Mohd, F., \& Said, J. (2015). Integrity systems in Malaysian public sector: an empirical finding. Procedia Economics and Finance, 28, 260-265.

Rothstein, B. O., \& Teorell, J. A. (2008). What is quality of government? A theory of impartial government institutions. Governance: An International Journal of Policy, Administration, and Institutions, 21(2), 165-190. 
Royce, T. (2018). MACC investigates GLC over RM108mil corruption. The Star.

Retrieved from https://www.thestar.com.my/news/nation/2018/03/05/macc-investigatesglc-over-rm108mil-corruption\#xbTtzoVpoF8A2p91.99

Storr, L. (2004). Leading with integrity: A qualitative research study. Journal of Health Organization and Management, 18(6), 415-434.

Thoroughgood, C. N., Sawyer, K. B., \& Hunter, S. T. (2013). Real men don't make mistakes: Investigating the effects of leader gender, error type, and the occupational context on leader error perceptions. Journal of Business and Psychology, 28(1), 31-48. http://dx.doi.org/10.1007/s10869-012-9263-8.

Veríssimo, J. M., \& Lacerda, T. M. (2015). Does integrity matter for CSR practice in organisations? The mediating role of transformational leadership. Business Ethics: $A$ European Review, 24(1), 34-51.

Wei, Y. S., O'Neill, H., \& Zhou, N. (2020). How does perceived integrity in leadership matter to firms in a transitional economy?. Journal of Business Ethics, 167(4), 623-641. https://doi-org.ezaccess.library.uitm.edu.my/10.1007/s10551-019-04168-x

Yukl, G. (2010) Leadership in Organisations (7th edn.) Prentice Hall.

Yukl, G., Mahsud, R., Hassan, S., \& Prussia, G. E. (2013). An improved measure of ethical leadership. Journal of leadership \& organisational studies, 20(1), 38-48. 